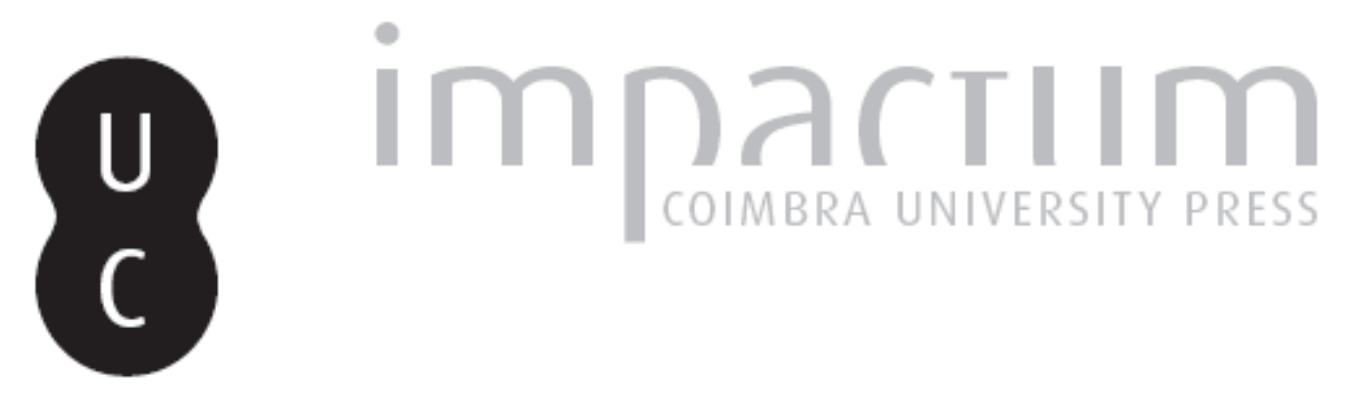

\title{
Seeing the forms
}

\section{Autor(es): $\quad$ Pesic, Peter}

Publicado por: Imprensa da Universidade de Coimbra

URL persistente:

URI:http://hdl.handle.net/10316.2/42218

DOI:

DOI:https://doi.org/10.14195/2183-4105_7_4

Accessed : $\quad$ 26-Apr-2023 12:19:20

A navegação consulta e descarregamento dos títulos inseridos nas Bibliotecas Digitais UC Digitalis, UC Pombalina e UC Impactum, pressupõem a aceitação plena e sem reservas dos Termos e Condições de Uso destas Bibliotecas Digitais, disponíveis em https://digitalis.uc.pt/pt-pt/termos.

Conforme exposto nos referidos Termos e Condições de Uso, o descarregamento de títulos de acesso restrito requer uma licença válida de autorização devendo o utilizador aceder ao(s) documento(s) a partir de um endereço de IP da instituição detentora da supramencionada licença.

Ao utilizador é apenas permitido o descarregamento para uso pessoal, pelo que o emprego do(s) título(s) descarregado(s) para outro fim, designadamente comercial, carece de autorização do respetivo autor ou editor da obra.

Na medida em que todas as obras da UC Digitalis se encontram protegidas pelo Código do Direito de Autor e Direitos Conexos e demais legislação aplicável, toda a cópia, parcial ou total, deste documento, nos casos em que é legalmente admitida, deverá conter ou fazer-se acompanhar por este aviso. 


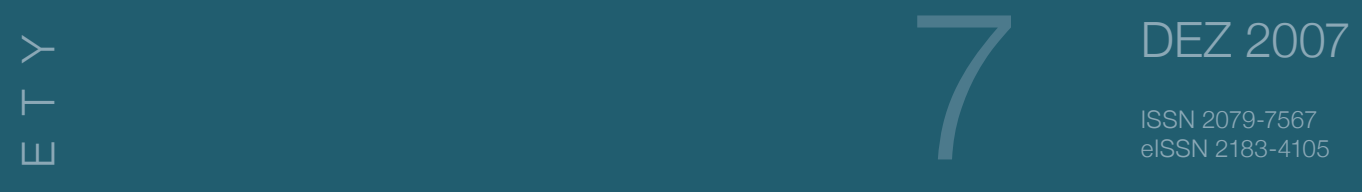

$-$

0

○

$\infty$

Established 1989

http://platosociety.org/

O

$\vdash$

$\varangle$

\lrcorner

口

-
$\varangle$
$Z$
0
-
-
$\varangle$
$Z$
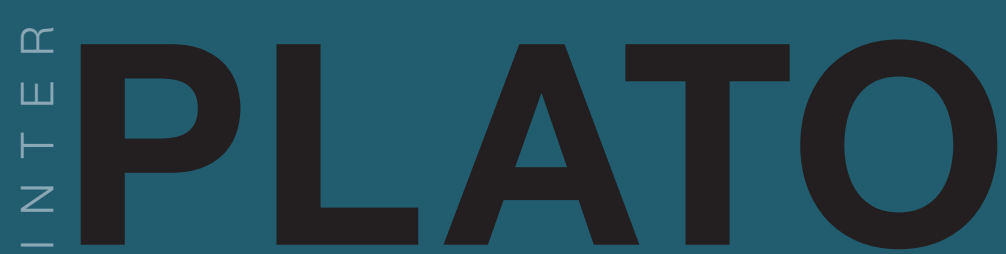

J0
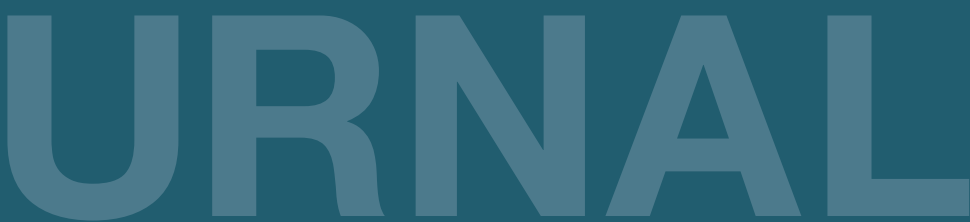

Société Platonicienne Internationale

Associazione Internazionale dei Platonisti

Sociedad Internacional

de Platonistas

Internationale

Platon-Gesellschaft 


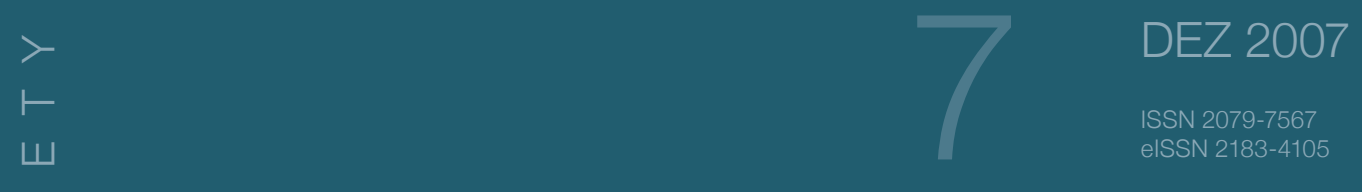

$-$

0

○

$\infty$

Established 1989

http://platosociety.org/

O

$\vdash$

$\varangle$

\lrcorner

口

-
$\varangle$
$Z$
0
-
-
$\varangle$
$Z$
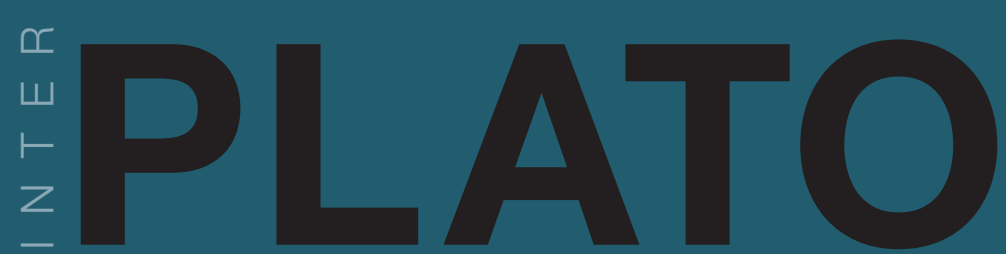

J0
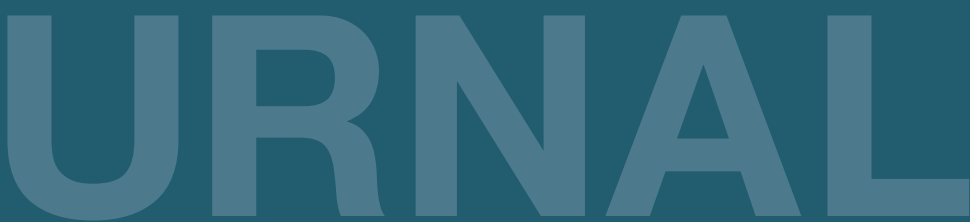

Société Platonicienne Internationale

Associazione Internazionale dei Platonisti

Sociedad Internacional

de Platonistas

Internationale

Platon-Gesellschaft 


\title{
SEEING THE FORMS
}

\begin{abstract}
We reexamine Plato's use of visual metaphors by considering his own treatment of light and sight, which differed from the later view that the eye is purely passive. Instead, he considered the eye to be active, sending out beams that contact the "outer fire" and then return to the seer. This essential activity of the act of seeing changes the way we should read many passages in Plato based on metaphors of vision, in order to bring forward the fundamental activity of the soul in knowing. Understood in this way, Plato's words eidos and idea may refer not only to self-subsistent, transcendent "forms" but also to the active process of "seeing" that connects us with them.
\end{abstract}

Metaphors of light and vision reverberate throughout Plato's dialogues. His accounts of being and knowledge turn on the words $\epsilon \hat{\imath} \delta o \varsigma$ and $\hat{i} \delta \varepsilon \dot{\varepsilon} \alpha$, crucial terms in what is often called his "theory of forms" or "ideas." 1 These words have a prior significance that comes from their direct reference to the act of seeing. Though much effort has gone into trying to recover Plato's original meaning, we have hitherto read his descriptions of seeing implicitly assuming that the eye is a passive receptor of light, like a camera. ${ }^{2}$ Yet Plato certainly did not understand vision in this way. In this paper, I will place his treatment of vision in the context of earlier Greek writings and explore their implications for understanding his visual imagery, especially the visual component of $\epsilon \hat{i} \delta \circ \varsigma$ and $\mathfrak{i} \delta \varepsilon \varepsilon$. To be sure, Plato's metaphorical use of vision may differ from the literal act of seeing, so that we must consider carefully how far we may extend insights derived from one to the other. Nevertheless, his repeated use of this metaphor indicates that he found important commonalities between sight and insight, if not in their objects, then in their respective processes. Hence we will probably go wrong if we substitute anachronistic treatments of vision for Plato's own very different views. Conversely, reengaging his views on vision leads to new readings of many passages and invites us to consider new perspectives on the essential activity of the soul in the process of knowledge. I do not pretend to treat this vast subject exhaustively but hope that what follows will open for further discussion the question: how does recovering Plato's own understanding of vision change our reading of him?

The derivation of $\epsilon \hat{\imath} \delta o \varsigma$ and $\mathfrak{i} \delta \varepsilon \dot{\varepsilon} \alpha$ has long been known. From the Indo-European root vid-comes the Sanskrit veda (to know), the Greek root $F_{1} \delta$ - found in verbs like $i \delta \in \hat{\imath} v$, the Latin video (which preserves the initial "w" sound of $F_{\imath} \delta$-, as does the archaic English word wot), and our word vision. ${ }^{3}$ As a noun derived from $i \delta \in \hat{\imath} v$, Homer uses

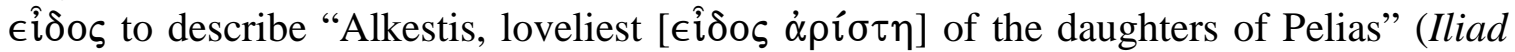
2.715), she of the best $\epsilon \hat{\imath} \delta o \varsigma$, the best looking. Likewise, Hector taunts Paris for his "beauty and $\epsilon \hat{i} \delta o \varsigma$ [

Thus, $\in \hat{i} \delta o \varsigma$ initially denoted something strongly physical and sensual, as in "good looks," in contrast to the abstract connotations of the Latinate word "form." 4 In Plato's Charmides, $\epsilon \hat{i} \delta$ o $\varsigma$ means especially the naked form of a beautiful person, the object of a lover's inflamed gaze (154d-e, 155d). By contrast, i $\delta \varepsilon \dot{\alpha}$ would not be used for this nakedness. ${ }^{5}$ Like our word "idea," i $\delta \varepsilon \dot{\alpha}$ suggests something more mental than does €î́os. Though our word "idea” implies a Lockean mental privacy (as in "my idea”), 
Plato's word i $\delta \varepsilon \dot{\varepsilon} \alpha$ is public, open, transparent, denoting a quality visible to all (as in "the ¡̇ $\varepsilon \alpha$ of even numbers”).

With this context in mind, consider the contrast between the view that the eye receives light passively and the earliest Greek description of the structure and function of the eye, by Empedocles:

As when a man, thinking to make an excursion through a stormy night prepares a lantern, a flame of burning fire, fitting lantern-plates to keep out every sort of winds, and these plates disperse the breath of the blowing winds; but the light $[\phi \hat{\omega} \varsigma]$ leaps out through them, in so far it is finer, and shines across the threshold with unwearying beams: so at that time did the aboriginal fire [ $\pi \hat{v} \rho]$, confined in membranes and in fine tissues, hide itself in the round pupils; and these [tissues] were pierced throughout with marvelous passages. They kept out the deep reservoir of water surrounding the pupil, but let the fire through [from within] outwards, since it was so much finer. ${ }^{6}$

The water of the eyeball contains a gentle fire that emerges from the pupil in beams, thus combining the fire of Strife with the water of Love, the two contending principles of Empedocles' theory. Here, the eye sees by extromission, projecting beams of light that contact objects. In another fragment, Empedocles asserts that every object emits effluences or emanations ( $\dot{\alpha} \pi \circ \rho \rho \circ \alpha i)$, films or particles that stream from their surfaces and can pass through certain passages, such as the pupil of the eye. ${ }^{7}$ So Empedocles' account somehow combines the extromission theory of vision with an intromission theory. Since we only have fragments of his writings, it is hard to know how he related these two, but evidently he felt the need of both elements.

Socrates ironically notes that Empedocles' theory of effluences ( $\dot{\alpha} \pi$ o $\rho \rho \alpha \hat{\imath})$ is just the sort of thing Meno is used to, the most up-to-date and fashionable "scientific" teaching of the day (Meno 76c-e). Socrates does not seem to think much of this "highsounding [ $\tau \rho \alpha \gamma \iota \kappa \eta$ ]" theory of effluences, as if such a notion could only captivate sophists like Gorgias or Meno. There may be an ironic echo between the related words

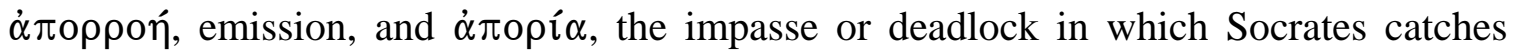
Meno. Socrates' own preferred alternative in this dialogue (that "shape is that which always accompanies color") does not explicitly address the question of vision. In other dialogues, Plato consistently advocates an extromission theory that does not include any reception of effluences or the like. Indeed, his friend Archytas of Tarentum, a prominent Pythagorean, had apparently also put forward a pure extromission theory, in which the beams sent out from the eyes are the sole means of vision. ${ }^{8}$ In response, Aristotle objected that if the eye sent out such beams, it should be able to see in perfect darkness. ${ }^{9}$

In contrast, the Greek atomists took up Empedocles' idea of effluences, now interpreted as atomic films they called $\epsilon \hat{\imath} \delta \omega \lambda \alpha$ (which Lucretius rendered as simulacra, semblances). The diminutive $\epsilon \hat{i} \delta \omega \lambda$ ov denotes a little $\epsilon \hat{i} \delta o s ;$ Homer used $\epsilon \hat{i} \delta \omega \lambda$ ov to mean a phantom, a ghost; later, it came to mean an idol. The atomists considered the eye radically passive, merely receiving the $\epsilon \hat{i} \delta \omega \lambda \alpha$, whose impact in the eye would register as sight. Aristotle steered between the opposite extremes of vision as pure projection or as pure reception. He concentrated on the medium between the eye and the object, locating the activity of light in the activation of the transparent. ${ }^{10}$ Even so, Aristotle gave 
a prominent place to the activity of the eye in seeing, consistent with his general description of sensation in terms of eating: for external objects to enter our mind, they must be digested and transformed, "metabolized" so that we can assimilate their external form into our own mind. ${ }^{11}$

However, more than a millennium after Plato, the extromission theory remained predominant. The intromission theory has many problems: How could the $\epsilon \hat{i} \delta \omega \lambda \alpha$ from a huge mountain fit through the tiny pupil of the eye? Why do more distant objects appear smaller than nearer ones of the same size? Already in the thirteenth century, Ibn alHaytham (Alhazen) rejected $\epsilon \hat{i} \delta \omega \lambda \alpha$ in favor of rays entering the eye. ${ }^{12}$ This geometric theory of light goes back to Euclid and Ptolemy, who considered that the eye projects the rays. After the seventeenth century, Descartes and others elaborated a ray theory of intromission; Newton advocated a theory in which light was small particles. Only after 1800 did the wave theory come into its own through the work of Thomas Young and Augustin Fresnel, among others. Though modern physical optics left it behind, extromission speaks powerfully to the phenomenology of seeing. We feel when someone is staring at us and we notice "eye contact." We speak of hard stares, even of staring daggers; "to gaze" means to look outward, contemplatively, as if something streamed from our eyes. Moreover, modern physiology interprets human vision not as passive reception by the eye but as a complex state of activity involving higher brain centers. ${ }^{13}$ Modern phenomenology still struggles to register the full import of these discoveries; Plato's "archaic" view of vision may finally turn out to be deeply important for current philosophy. ${ }^{14}$ For instance, though Jacques Derrida noted about Edmund Husserl's account of the origin of geometry that "to constitute an ideal object is to put it at the permanent disposition of a pure gaze," Derrida did not go on to remark the importance of Plato's account of the activity of that gaze, whose profound constitutive function must be of the greatest importance for geometry and thus needs much further examination. ${ }^{15}$

The Timaeus contains Plato's most detailed presentation of the mechanism of vision, especially how the eye's extromission interacts with the outer world. Timaeus hails from Locri, whose nearness to Archytas's Pythagorean center in Tarentum may indicate the closeness in their views. In Timaeus's account, after the demiurge shaped the cosmos, he allowed lesser gods to make humans and give them vision (45b-46a). Compressed by the eye and projected through the narrow opening of the pupil, a "smooth and dense" fire beams out from the eye. That stream of inner fire interacts with "the outer fire of day," the "external" light in the world that Timaeus calls the "brother" of the fire within us. When this happens, the "entire stream of vision" becomes an almost palpable thread that can touch that which it encounters. Then certain "motions" are transmitted through the thread of vision "throughout the entire body until they reach the soul" to produce the sensation of vision. Accordingly, in this account vision requires interaction between inner and outer fire, in which the beam going out from the eye is the crucial first step, without which external light by itself cannot force its way into the eye and register as sight.

This view also addresses Aristotle's objection about seeing in the dark, though Aristotle does not seem to recognize or address this solution. Timaeus argues that if the outgoing beam from the eye encounters not its "brother," fire, but its dissimilar counterpart, darkness, then the eye's beam is "utterly quenched." In that case, the interaction between inner and outer fire does not occur and the inner fire retreats within 
the eyeball. The eyelids close sleepily and the trapped inner fire gives rise to phantasms, flickering images we experience as dreams because the fires trapped inside are "remembered as outside by those who have awakened." If dreams reproduce the felt quality of external reality, they confirm that the process of vision happens essentially from "inside."

Dreams also show the limitations of vision cut off from outer light. In the Republic, Socrates remarks that "surely some terrible, savage, and lawless form [ $\epsilon \hat{i} \delta o \varsigma]$ of desires is in every man, even in some of us who seem to be ever so measured. And surely this becomes plain in dreams" (572b). In the soul of the tyrannical man, "the opinions that were formerly released as dreams in sleep” now run riot in daylight, so that "what he had rarely been in dreams, he became continuously while awake. He will refrain from no terrible murder, or food, or deed" (575d-e). The tyrant's world is a nightmare because his vision does not contact what truly is. Yet these same emanations from the eyes can reach out and give us real vision; we cannot see or know without them. If the word $\epsilon \hat{i} \delta o \varsigma$ refers to the essence of vision, it directs our attention toward the activity of our seeing no less than to archetypes we may discern outside of us. As such, it forms an important complement to Timaeus's description of each $\epsilon \hat{i} \delta$ o $\zeta$ subsisting "itself by itself

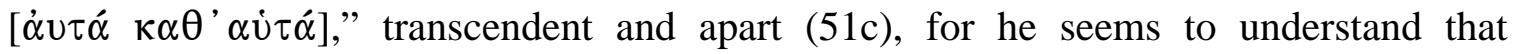
apartness as open to our seeing, understood as a beam emanating from our soul. Indeed, the conjunction of inner and outer fire, of the beam enacting our knowing along with its transcendent object, may be an ideal example of the "indeterminate dyad [ $\alpha$ ó

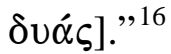

Reading the Republic with this in mind casts a new light on many passages. Consider the story told in Book VI of a mutiny aboard a ship, whose owner, though he "surpasses everyone on board in height and strength," is "rather deaf and somewhat short-sighted" (488b). This flaw in his vision keeps him from being a true pilot and allows the sailors to quarrel and delude themselves that they know how to pilot. They call the true pilot a "stargazer [ $\mu \epsilon \tau \epsilon \omega \rho о \sigma \kappa o ́ \pi о \varsigma]$ " (488e), one who gazes at $\tau \grave{\alpha} \mu \epsilon \tau \varepsilon$ c $\omega \rho \alpha$, the things above, those high or exalted. His gaze is not "short-sighted" but directed on high, where he discerns the stars he steers by. Those heavenly bodies remain mute oracles, not forms of knowledge until his eyes reach out to touch them.

The interpretation of the myth of the cave in Book VII also depends critically on the nature of light and vision. Though the sun is far outside, its light penetrates into the deepest recesses of the cave, which Socrates first depicts as "open to the light across the whole width of the cave," as if the sun were the source of the light. But then we read that "their light is a fire burning far above and behind them," casting the shadows at which the cave-dwellers wonder. These are evidently not contradictory lights, even though the text specifies that the shadows are cast "by the fire." The simplest explanation is that the nature of light is the same, whether coming from fire or sun, differing only in intensity. Even the darkness-dimmed eyes of the cave-dwellers are able to discern that light, though surrounded by shadows. This indicates an essential connection between images and intelligibles. Though Socrates denigrates $\epsilon \hat{\imath} \delta \omega \lambda \alpha$, the word he uses for images in mirrors, he does not deny their ultimate connection with the realm of $\epsilon \hat{\mathfrak{i} \delta} \varsigma_{\text {. }}{ }^{17}$

Socrates also insists that education, as leading one outside the cave, occurs not "as though they were putting sight into blind eyes," as the sophists claim. Socrates goes on to emphasize that 
"the present argument, on the other hand," I said, "indicates that this power

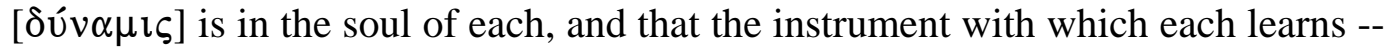
just as an eye is not able to turn toward the light from the dark without the whole body -- must be turned around from that which is coming into being together with the whole soul until it is able to endure looking at this which is and the brightest part of that which is. And we affirm that this is the good, don't we?” (518d)

The "power" that is "in the soul of each" is the power to see the light, whether dim or bright, sun or distant fire. Though surely the source of vision is in some sense the sun, the Good, Socrates stresses that this power is in the soul of each, meaning the beam of inner fire that each can direct outward to meet the light outside.

Speaking about the final stage of the education of the philosophers, Socrates notes that "we shall require them to turn upwards the vision of their souls and fix their gaze $[\dot{\alpha} \pi \circ \beta \lambda \dot{\varepsilon} \psi \alpha \mathrm{l}]$ on that which sheds light on all," namely the good itself (540a). Here,

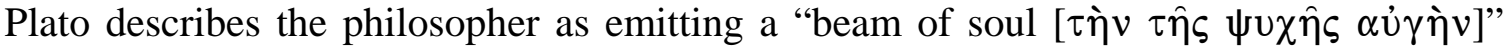
that meets the light of the good. Again, this light is not restricted to those with "gold" souls, for the noble lie is false, however socially useful (415a). Perhaps Plato means this lie as a provocation to the nobility of his hearers, who may then be moved to realize that their ability to see and understand is not peculiarly theirs, nor restricted to them.

If indeed "this power is in the soul of each," it must be a central concern of human life, for even if the Good exists apart from us, radiant and immortal, it will be nothing to us without the light emerging from within us. Plato's choice of the word power ( $\delta \dot{v} v \alpha \mu \iota \varsigma$ ) does not merely indicate a faculty that is simply given, but rather an ability that can be exercised and kept active or allowed to degenerate. Socrates also tells us that this power must be rightly turned towards that which is brightest, specifically by turning the eye along with the whole body, symbolizing the entirety of the soul. The crucial exercise of this power we have is that we can, at each moment, turn it in one direction or another, as we can direct our gaze hither or yon. ${ }^{18}$

Our gaze cannot be guided by compulsion, as Socrates indicates by insisting that "instruction must not be given the aspect of a compulsion to learn" (536d). This calls us to reconsider the language of compulsion Socrates uses about a hypothetical man "compelled to stand up, turn around, to walk and look up toward the light," seemingly dragged by force out of the cave (515d-516a). If this is to be consistent with his avoidance of compulsion, Socrates would mean that our gaze cannot and should not be so compelled. The apparent paradox of his language here reflects an artistic choice: the language of compulsion in the inner frame of the dialogue provokes our souls, in its outer frame, to consider freely what it would mean for us to turn our gaze to the light.

We have learned from Friedrich Schleiermacher and Jacob Klein to read Plato's dialogues as dramas, attuned to his choice of setting and characters. ${ }^{19}$ But we should also consider Plato's dialogues as paintings, attending to the way he works with our seeing. Indeed, his dramatic strokes often depend on creating visually arresting tableaux, as when Thrysymachus blushes (Republic 350d). Consider also the scene of Leontius passing by some executed corpses (Republic 439d-440a); he "desired to look, but at the same time he was disgusted and made himself turn away; and for a while he struggled and covered his face. But finally, overpowered by the desire, he opened his eyes wide, ran toward the 
corpses, and said: 'Look, you damned wretches, take your fill of the fair sight.' " Here, the drama precisely evokes his struggle whether or not to see, depicted so vividly that we, in turn, must consider what we will see in it. As such, this scene is a dark reflection of the luminous ascent from the cave. When Socrates speaks of compelling his hypothetical man to look up toward to the light, we in turn realize that we can always shut our eyes or turn away. The picture of Leontius takes us one step further. The more we gaze at his struggle whether to look, the more we discern the implications of how and where we look. Plato's philosophical painting acts to draw our gaze because, however strong his effects, they are nothing without our looking at them.

To be sure, Plato famously criticized painters for being imitators and distinguished true intellection from mere seeing. ${ }^{20}$ But no less did he criticize the lies of the poets even as he shaped his new philosophical dramas. The irony of a great artist critiquing art pervades Plato's works and paradoxically intensifies the way we look at them, thereby also giving them their truly philosophical character. Plato's tableaux achieve a kind of painterly permanence by provoking us to reactivate them by our own acts of seeing. If Plato wants us, too, to be "lovers of the sight of truth [ $\phi \mathrm{\imath} \lambda \mathrm{o} \theta \epsilon \dot{\alpha} \mu \mathrm{ov} \alpha \varsigma]$ " (475e), he must summon us to see willingly. ${ }^{21}$ Socrates also discloses a prime artistic principle of such summoning, which he explicitly links to the practice of painters: the things that summon the intellect are those "that at the same time go over to the opposite sensation" (523c). He is critical of visual arts that do not do this, meaning those that act as if sensation were perfectly adequate and unproblematic. Indeed, his very understanding of vision itself critiques the kind of thoughtless viewing in which inner and outer fires do not adequately engage. Socrates takes his own advice in his "painting" of the cave, summoning our intellects by feigning to compel what cannot be compelled -our active vision and assent. In the Republic, he notes that, though his eyes would hurt at first, the man who leaves the cave eventually would "make out the sun -- not its appearances in water or some alien place, but the sun itself by itself in its own region -and see what it's like” (516b). Yet Socrates notes in Phaedo 99d that it is dangerous to gaze directly at the sun "unless they study its reflection in water or some other medium." These contradictions summon us to reflect on the differences between literal and metaphorical "seeing," between the sun and the Good. Even here, though, Plato only contrasts the objects of sight without indicating any fundamental difference in the process of "seeing."

With this in mind, we can turn to the vexed problem of how individual good things "participate" in the $\epsilon \hat{\imath} \delta o \varsigma$ of the Good. Here, Plato's verb $\mu \in \tau \varepsilon \dot{\varepsilon} \chi \in \mathfrak{l} v$ literally means "meta-having": having in common, in co-operation, not alone or in isolation. Plato's account of vision is precisely a "participation," the co-operation of the light streaming from our eye and the light outside, its "brother," as Timaeus puts it. Individual instances of the good thus stream out from the mind to the Good that then informs them, exactly paralleling the way that our vision reaches out from us, contacting $\epsilon \hat{i} \delta o \zeta$ in the process, and returns to us in turn. ${ }^{22}$ Such an interactive phenomenology gives a far more convincing account of "participation" than does a merely static and abstracted sense of "inclusion."

Above all, Plato understands that this metaphorical act of "seeing," like the literal acting of beholding, is not fixed but able to change profoundly, to metamorphose into a far deeper act of recognition. Near the end of the Sophist, the young Theaetetus and the 
Stranger weigh the possibility that all things come forth spontaneously, without intelligence, or that they have a reasonable and divine cause. Theaetetus then says, "I often go back and forth between the two opinions, perhaps because of my age. Yet now, as I look at you [ $\beta \lambda \dot{\varepsilon} \pi \omega \nu \in i \zeta \sigma \grave{\varepsilon}]$ and gather that you think they come to be in accordance with god, I myself also adopt this belief" (265d). ${ }^{23}$ Because of the way he looks at the Stranger, Theaetetus reaches a new view. Likewise, near the end of the Republic, Socrates asks Glaucon:

"Haven't you perceived,” I said, “ that our soul is immortal and is never destroyed?"

And he looked me in the face with wonder $[\dot{\varepsilon} \mu \beta \lambda \varepsilon \dot{\varepsilon} \psi \alpha \varsigma \mu$ or $\kappa \alpha i$ $\theta \alpha u \mu \alpha ́ \sigma \alpha \varsigma]$ and said, “No, by Zeus, I haven't. Can you say that?” (608d)

Surprised at the idea that the soul may be immortal, Glaucon's own soul flashes forth in the look he gives Socrates full in the face $(\dot{\varepsilon} \mu \beta \lambda \dot{\varepsilon} \psi \alpha \varsigma)$, as Plato so carefully depicts. This may be the very moment Glaucon's own immortality shines out, at least in our eyes. We remember that Glaucon's name means "gleaming” ( $\gamma \lambda \alpha \cup \kappa o ́ \varsigma)$, also connoting a bluishgray color, as of the sea or perhaps of his own eyes. His name denotes a certain intense gleam, as from the sea -- the kind of look Glaucon gave Socrates at that charged moment. Plato may here affix a more secret, personal signature to this special page, gazing at his brother Glaucon's gaze, brother meeting brother as light meets light. Perhaps if we contemplate such looks, we too will begin to see.

Peter PESIC

St. John's College, Santa Fe

References

${ }^{1}$ From the vast literature on this subject, I will mention David Ross, Plato's Theory of Ideas (Oxford: Clarendon Press, 1951) and, more recently, R. M. Dancy, Plato's Introduction of Forms (Cambridge: Cambridge University Press, 2004), Gail Fine, Plato on Knowledge and Forms: Selected Essays (Oxford: Oxford University Press, 2003), Plato's Forms: Varieties of Interpretation, ed. William A. Welton (Lanham, Md.: Lexington, 2002), A. H. Coxon, The Philosophy of Forms: An Analytical and Historical 
Commentary on Plato's Parmenides, with a New English Translation (Assen, Netherlands: Van Gorcum, 1999), John Malcolm, Plato on the Self-Predication of Forms: Early and Middle Dialogues (Oxford : Clarendon Press, 1991), E. E. Benitez, Forms in Plato's Philebus (Assen, Netherlands: Van Gorcum, 1989). For the case against a "Platonic theory of Forms," see Francisco J. Gonzales, "Plato's Dialectic of Forms," in Plato's Forms, 31-83.

${ }^{2}$ For general histories of light and vision, see Vasco Ronchi, The Nature of Light: An Historical Survey, tr. V. Barocas (Cambridge: Harvard University Press, 1970), David Park, The Fire Within the Eye (Princeton: Princeton University Press, 1997), and (more particularly concerning the light from the sky) Peter Pesic, Sky in a Bottle (Cambridge, Mass.: MIT Press, 2005).

${ }^{3}$ For the Indo-European roots, see Julius Pokorny, Indogermanisches Etymologisches

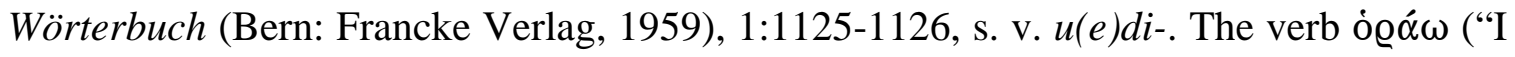
see, in the sense of perceive, be aware of") has the aorist $i \delta \in \hat{\imath} v$ ("to have seen, grasped") and perfect oi $\delta \alpha$ ("I have seen," in the present, completed sense "I know"). Compare

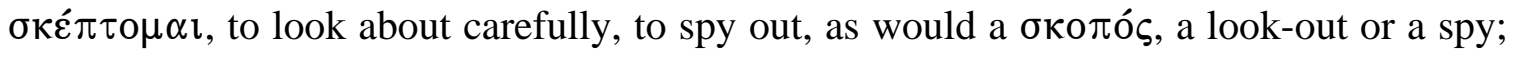
hence to view, examine, consider. From this comes $\sigma \kappa \varepsilon \dot{\psi} \iota \varsigma$, meaning viewing, perceiving by the senses, but also hesitating, doubting.

${ }^{4}$ To emphasize this visuality, Jacob Klein suggested that we translate $\epsilon \hat{\mathfrak{i} \delta} \varsigma$ as the "look" of something, though here meaning what he calls its "invisible look," its figure or essential shape; see Jacob Klein, Plato's Trilogy (Chicago: University of Chicago Press, 1977), 3.

${ }^{5}$ This despite that fact that $\epsilon \hat{i} \delta o \zeta$ and $\hat{i} \delta \varepsilon \varepsilon$ are sometimes treated as synonyms; see Henry George Liddell and Robert Scott, A Greek-English Lexicon (Oxford: Clarendon Press, 1968), 482, s. v. $\epsilon \hat{i} \delta$ os.

${ }^{6}$ Fragment 84 in Hermann Diels and Walther Krantz, Die Fragmente der Vorsokratiker (Zurich: Weidmann, 1992), 342, cited by Aristotle in his Sense and Sensibilia, 437b26438a2, as translated in Ancilla to the Presocratic Philosophers: A Complete Translation of the Fragments in Diels, Fragmente der Vorsokratiker, tr. Kathleen Freeman (Cambridge, Mass.: Harvard University Press, 1978), 60-61.

${ }^{7}$ Ibid., fragment 89, cited by Plutarch, Quaestiones naturales 19, 916d: "Realizing that from all created things there are effluences [ $\alpha \dot{\pi} \rho \rho \rho o \alpha i]$...” (translation p. 61). I will shortly return to this issue in the context of Meno 76c

${ }^{8}$ See Ronchi, The Nature of Light, 8.

${ }^{9}$ Aristotle, Sense and Sensibilia, 437b1-23.

${ }^{10}$ By this he may have meant something strikingly like the fields that Michael Faraday and James Clerk Maxwell used to express light as a manifestation of electromagnetism; see Peter Pesic, “The Fields of Light,” St. John's Review 38:3, 1-16 (1988-1989) and Seeing Double: Shared Identities in Physics, Philosophy, and Literature (Cambridge, Mass.: MIT Press, 2002), 69-84.

${ }^{11}$ Aristotle, On the Soul 416a19-416b29.

12 The Optics of Ibn al-Haytham, tr. A. I. Sabra (London: Warburg Institute, 1989), 1:1338, and Ronchi, The Nature of Light, 45-57.

${ }^{13}$ For a theoretical view of brain activity in vision, see Christof Koch, The Quest for Consciousness: A Neurobiological Approach (New York: Roberts and Co., 2004); for 
classic case studies, see Oliver Sacks, An Anthropologist on Mars: Seven Paradoxical Tales (New York: Vintage, 1996) and The Island of the Colorblind (New York: Vintage, 1998).

14 For instance, Maurice Merleau-Ponty, Phenomenology of Perception (London: Routledge, 1958) claims to "give up any attempt to define sensation as pure impression" (5) but still struggles with the "reception of images." Though "the look" (le regard) is of great importance for Jean-Paul Sartre, Being and Nothingness: A Phenomenological Essay on Ontology, tr. Hazel E. Barnes (New York: Washington Square Press, 1956), 340-400, Sartre characteristically emphasizes 'the Other's look as the necessary condition of my objectivity" (360), meaning specifically "a look-looking and not a look-looked-at," so that here my looking is essentially constituted by being-looked-at by the Other rather than by looking myself. The contrast with Plato is extreme and provocative, turning on the nature of vision: where Plato emphasizes the essentiality of how I look at others (the fire streaming from my eyes), Sartre implicitly relies on the intromission theory of vision in his emphasis on the Other's look penetrating me. I thank Victoria Mora for drawing my attention to these passages in Sartre. It seems to me that Emmanuel Levinas is moving in the direction I have indicated here when, in his discussion of "Sensibility and the Face" in his Totality and Infinity: An Essay on Exteriority, tr. Alphonso Lingis (Pittsburgh, PA: Duquesne University Press, 1969), 187-193, at 189, he writes that, "[a]s Plato noted, besides the eye and the thing, vision presupposes the light. The eye does not see the light, but the object in the light. Vision is therefore a relation with a 'something' established within a relation with what is not a 'something.' We are in the light inasmuch as we encounter the thing in nothingness. The light makes the thing appear by driving out the shadows; it empties space. It makes space arise specifically as a void. Inasmuch as the movement of the hand that touches traverses the 'nothing' of space, touch resembles vision."

${ }^{15}$ Jacques Derrida, Edmund Husserl's Origin of Geometry: An Introduction, tr. John P. Leavey, Jr. (Lincoln, NE: University of Nebraska Press, 1989), 78. I hope on another occasion to explore the implications of the interconnection of $\epsilon \hat{\mathrm{i} \delta}{ }_{\mathrm{S}}$ and vision for the origin and understanding of geometry.

16 See Jacob Klein, Greek Mathematical Thought and the Origin of Algebra, tr. Eva Brann (New York: Dover, 1992), 82-99.

${ }^{17}$ For $\epsilon \hat{\imath} \delta \omega \lambda \alpha$ as images in mirrors, see Timaeus 46a-c, in which the projected beam from the eye meets the light reflected from the mirror so as to create a reversed image.

18 As Jacob Klein, A Commentary on Plato's Meno (Chapel Hill: University of North Carolina Press, 1965), 105, emphasizes about Socrates' dialogue with the slave boy, "the assent and the rejection came from nobody but the boy himself' (emphasis original).

19 See Schleiermacher's Introductions to the Dialogues of Plato, tr. William Dobson (New York: Arno Press, 1973), 20, and Klein, Commentary on Plato's Meno, 3-10.

${ }^{20}$ Here I differ from Iris Murdoch's view that Plato would have regarded the paintings of Mondrian "as histrionic and dangerously sophisticated," in The Fire and the Sun: Why Plato Banished the Artists (Oxford: Clarendon Press, 1977), 16. I suggest that there may be paintings Plato would not have considered mere imitations but truly philosophical, not by virtue of their content but by the way they intensified and transformed ordinary seeing. In Paul Cézanne's paintings of Mont Sainte-Victoire, we can feel every stroke, 
feel his struggle to choose their precise color and place them on the canvas, whose bare presence shines through as if to remind us of the primal blankness with which these significant touches are in dialogue. Against the assumption that painting is simple imitation, Cézanne told a friend that "painting from nature is not copying the object, it is realizing sensations,” in Joachim Gasqet's Cézanne, tr. Christopher Pemberton (London: Thames and Hudson, 1991), 46. Gazing up at the mountain, Cézanne even saw Plato's cave: "During the day shadows seem to creep back with a shiver, as if afraid of them. High up there is Plato's cave: when large clouds pass overhead, notice how the shadow falling from them quivers on the rock as if it were being burnt up, instantly consumed by a fiery mouth” (152). No less do Rembrandt's self-portraits engage the seeing of seeing itself, his gaze meeting ours, regarding himself even as we gaze in return.

21 Note in this context the significance of the verb $\theta \epsilon \omega \rho \varepsilon \dot{\omega}$ ("I look at, behold, contemplate, observe, speculate”), whose middle voice $\theta \epsilon \dot{\alpha} о \mu \alpha \imath$ means "I behold with a sense of wonder." From these words come $\theta \varepsilon \dot{\varepsilon} \alpha \mu \alpha$, a spectacle, $\theta \epsilon \omega \rho$ ó $\varsigma$, an envoy sent to consult an oracle, $\theta \dot{\varepsilon} \alpha \tau \rho o v$, a theater, $\theta \epsilon \omega \rho \eta \mu \alpha$, a theorem, and finally $\theta \epsilon \omega \rho i \alpha$, a theory. In each case, something perhaps from a god must be seen, grasped by the beholder: the oracle avails nothing unless you receive it.

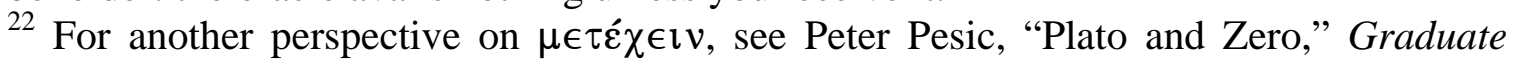
Faculty Philosophy Journal 25(2), 1-18 (2005).

${ }^{23}$ Compare $\beta \lambda \varepsilon \dot{\varepsilon} \pi \omega$ ("I look”) and its aorist $\varepsilon \beta \lambda \in \psi \alpha$ ("I cast a glance at”), here conjuring up a moment of vision, both fleeting and charged. The neutrality of mere looking is changed by prefixes: $\dot{\alpha} \pi \circ \beta \lambda \dot{\varepsilon} \pi \omega$ means "I gaze steadfastly at, I pay attention, I regard," and $\dot{\varepsilon} \mu \beta \lambda \dot{\varepsilon} \pi \omega$ means "I look in the face.” Here, looking has become gazing. 